
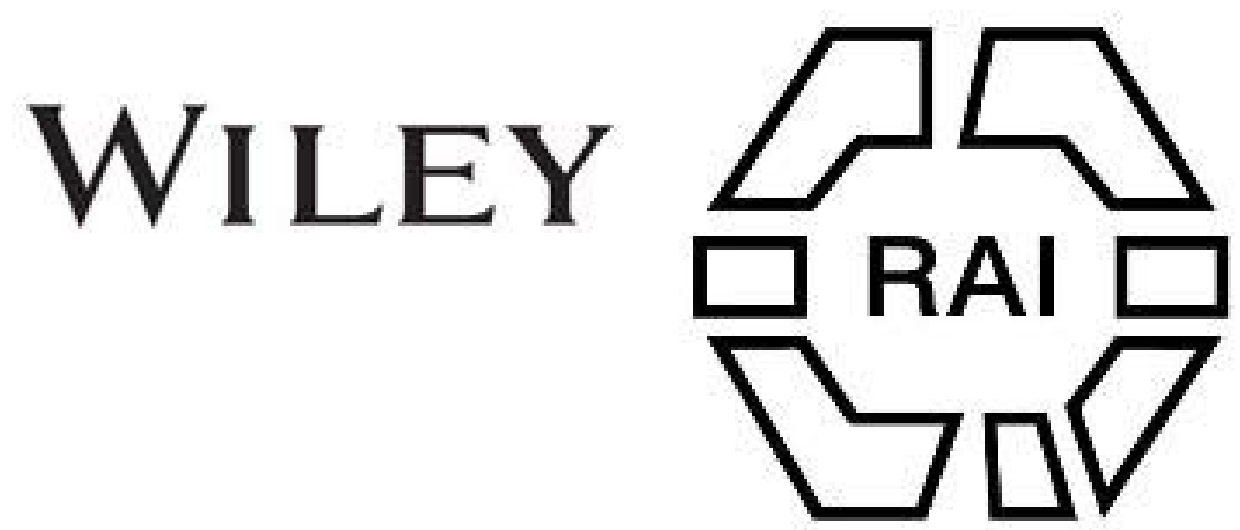

On the Medicine-Men of the Ten'a

Author(s): J. Jetté

Source: The Journal of the Royal Anthropological Institute of Great Britain and Ireland, Vol. 37 (Jan. - Jun., 1907), pp. 157-188

Published by: Royal Anthropological Institute of Great Britain and Ireland

Stable URL: http://www.jstor.org/stable/2843252

Accessed: 03-06-2016 14:20 UTC

Your use of the JSTOR archive indicates your acceptance of the Terms \& Conditions of Use, available at

http://about.jstor.org/terms

JSTOR is a not-for-profit service that helps scholars, researchers, and students discover, use, and build upon a wide range of content in a trusted digital archive. We use information technology and tools to increase productivity and facilitate new forms of scholarship. For more information about JSTOR, please contact support@jstor.org.

Wiley, Royal Anthropological Institute of Great Britain and Ireland are collaborating with JSTOR to digitize, preserve and extend access to The Tournal of the Royal Anthropological

Institute of Great Britain and Ireland 


\title{
ON THE MEDICINE-MEN OF THE TEN'A.
}

\author{
BY THE REV. J. JETTÉ.
}

The following sketch is exclusively limited to a branch of the widespread Athabaskan stock, living in the central part of Alaska, on the Yukon River and its tributaries from Tanana down to Koserefsky. The distance between these extreme points is about 440 miles, and the natives scattered over this region may number 2,000 souls, but hardly more. Nulato occupies a central position in this tract, being at 200 miles below Tanana and 240 above Koserefsky. The natives directly depending on the Nulato Mission for spiritual assistance are distributed over an area; 200 miles long, from Narardotitten (Na'ha'hdotitten), 70 miles above Nulato, to Blackburn, 130 miles below Nulato. By actual count of the names entered on the Mission Records, they number 700 and some odd souls. Supposing the remainder of the area above mentioned to be proportionally populated, which is rather to underrate its population, the total number ought to be 1,540. Making an allowance for the names not entered on the Mission books, one will easily admit that the group of Indians to whom this paper refers is composed of more than 1,600 and less than 2,000 individuals. In 1883, one of the most accurate explorers of Alaska, Frederick Schwatka, estimated their number to be between 1,200 and 1,500 people (Compilation of Narratives of Explorations in Alaska: Washington, Government Printing Office, 1900, p. 349).

They will be called in this paper Ten'a, a word which, in their language, means man or mon, and is found with the same meaning in the languages of related tribes, under the forms Tinneh, Dēne, Dindjie, Tindjit, etc. To the Russians they were known as Ingaliks or Ingaleets, an offensive appellation, meaning "the Lousy," given to them by their Eskimo neighbours, who deserve it much more. The group here concerned is neatly divided in two tribes which join precisely at Nulato. This place is, on account of the fact, occasionally designated by them as nit-ro-tenatadlerunten (nit-'ho-tenatadle'hunten), literally, the place where we are knotted together.

The locality and the people referred to being thus defined, let us proceed.

The Ten'a lore has it that in the old, old times three men started out a-hunting together. Two of them were very rich and influential in their iribe; the other was poor but smart and "brainy." After many wanderings, they began to starve; and as no game offered itself, the "brainy" man proposed to go back. The others laughed him to scorn, notwithstanding which he started to return home, they pursuing their adventure. They roamed about, to the very ends of the earth, continually pressed by hunger, sleeping in the open, and undergoing all kinds of 
hardships. They were growing thinner every day, their skins were tanned, their hair grew long and tough, their clothes were torn to rags. They looked more like wild beasts than like men, and began to live as animals. Finally, they were transformed the one into a wolf, the other into a wolverine. And this is the reason why, up to this day, when a Ten'a hunter kills one of those animals, it is brought, in great pomp, to the camp. "The chief is coming," they say to each other. The village goes out to meet him. The dead animal is brought into a cabin; the medicine-man spreads a red blanket before it and arranges it into a sitting posture. Then they proceed to offer him a banquet, each family sending a dish well filled with the best food they can procure. These are placed on the blanket, and when the lord of the forest is supposed to have enjoyed them enough and satisfied his posthumous appetite his admirers do the eating for him, and they acquit themselves of the task very creditably indeed. No woman is allowed to taste of the offered dishes, men only being entitled to eat the wolf's or the wolverine's banquet. So much for the two desperate adventurers. The third one, on his homeward journey, was beset with wonderful trials, passing through forests where the trees entered into a dance around him, canoeing through narrows where the huge cliffs moved to and fro, as enormous jaws trying to devour him; but when he finally reached his village, after a long absence, he was endowed with supernatural powers. He had become a medicine-man, and this is the first record of a medicine-man in the fabulous annals of the Ten'a.

For the understanding of what has to be said it will be useful to remark, before going any further, that the Ten'a have a wonderful faculty for believing or disbelieving what they choose. Their intellect seems to be altogether at their will's command, ready to give or refuse its assent according to the direction which it receives from the will. They never judge of the credibility of a report or statement on the merits of the case. Their criterion is neither the intrinsic credibility of the fact, nor the extrinsic evidence of testimony that may accompany it-although they are generally inclined to believe whatever is being said. The ultimate reason, which can be detected in almost, every instance as the one that really determines their belief, is: what benefit shall accrue to me from such a belief? If they see in it their own advantage, nothing more is required. To illustrate this statement, I may be allowed to quote from personal experience. Many a time have Ten'a people offered to me to believe all my teachings and profess themselves Christians, for the consideration of a sack of flour, or a pound of tea, or a head of tobacco. And when I answered that I did not care for such neophytes, they laughed at my simplicity, but I am sure they did not understand the reason of it. Notwithstanding this reply, however, which has been given them hundreds of times, as late as Christmas 1905, they came in a deputation to the Nulato Mission, to make some arrangements about the Christmas celebrations, requesting that the Mission would contribute a gift to the rejoicings of the people, " and," they added, "if you do so, we shall all believe your teaching, without exception." 
This disposition is the cause of the phenomenal credulity with which they accept all the absurd sayings of the medicine-men, because they fear woeful consequences if they refuse to believe. Similarly it causes the equally transcendent incredulity with which they disbelieve any teaching that does not suit their taste with an obstinacy that sets at defiance the most stringent and persuasive arguments of our logic.

This frame of mind is partly bred in them, but mostly acquired through the constant and sedulous exertions of their parents, relatives and friends. When the mind of a child has once been thoroughly bent to believe several of those absurdities, for reasons about as absurd as the things themselves, it loses, as it were, its natural independence. It judges of things no longer according to what it sees in them, but according to what is said about them, and the noblest faculty of man is dulled and number to practical uselessness. I do not know whether all savages present this phenomenon of intellectual degradation, but I have repeatedly noticed it in these. And it is a painful sight indeed, for one trained to think and reason, to see so many of his fellow-creatures trained, so to speak, to unthink and unreason.

The religious tenets of these people are most rudimentary. They have no religion, in the proper sense of the word, i:e., inasmuch as religion implies the relations of man with the Deity. They have even no notion of God, and seem to have been, for ages back, devoid of any knowledge of the Supreme Being. All their belief is centred on the devils. They know of nothing else that transcends the visible world. But the existence, the power, the continual action around them of the evil spirits, are things as familiar to their minds as is to us the notion of Divine Providence or of the power of the Almighty. And since, as has just been remarked, their power of belief is very great, the intensity as well as the extent of their devil-belief is beyond our conceptions. Their imagination is always on the alert to descry some devil moving about in the dark or in the broad daylight, as the case may be, and no caprice of the unruly fancy is too strange for them to believe. Hence, to hear them talk, one would think that they are constantly in touch with the devil, that they have seen it hundreds of times, and that they know by their names almost the whole court of His Satanic Majesty. Any one of the older folks on this subject would put Leo Tascil in the shade. Instances might be adduced without end, but, to keep within the bounds, I shall only quote two.

Last year, a native of Koyukuk Station, Thomas Dat'on, who is not a medicine-man, nor the near relative of a medicine-man, and who in practical matters is a sensible fellow, perfectly straight and square in his dealings, a married man with a little family of three nice children, and whom I have every reason to think perfectly sincere, related to me, very seriously and in great earnest, the following fact. It happened in March, 1905. "I was on the spring hunt," he said, "walking alone in the woods. I heard some noise behind me, as of one walking, and suddenly, before I had time to turn and look, I was 
seized around the waist by what seemed to be a short man about four feet high. The two hands, as black as that stove," and he pointed to one near by, "clutched in front of me, were all I could see of the fiend. His grasp was strong, but, besides, I felt inwardly overpowered. Although my arms were free, I had not the strength to raise them in defence. My breath almost failed me; my heart was beating as if wanting to jump out of my breast, and I was sweating profusely. I made some feeble efforts to disengage myself, but I felt powerless. I was conscious that the one holding me was a devil, though I could not see him. Then I tried to remember the words of prayer, but not one came to my mind. I made more and more efforts, till, at last, I recalled some few words which I had heard in the church. As soon as I uttered them the grasp of the black clutches began to loosen. At the same time my memory seemed to grow stronger; I succeeded in repeating a whole sentence. Upon which I suddenly felt myself free. There was a running behind: I turned, and saw a black thing disappearing among the trees." It would be useless to relate the argument which we had over this. Suffice it to say that no reasons of mine could convince him of his mistake, nor even give him the slightest doubt: he had seen and felt; and how could he doubt?

In January, 1906, I happened to be talking, at Kaltag, with Augustus Tsaika, a man about thirty-five or forty years of age, who has had successively two wives, the last one dying in the fall of 1905. Wo were speaking of the medicine-men and their devils. "Well,", said Tsaika, "I am not a medicine-man but I have seen devils many times. Once, we were about fifteen in a cabin, on the Innoko River. It was rather late at night. I went out. The door was not opening directly outside but into a sort of a shed, having large openings on both sides. It was bright moonlight and the floor of the shed was as white as snow, the moon shining on it. As soon as I stepped out of the cabin, I saw a black thing, shaped exactly as a man, but shorter, lying on the floor in the white moonlight. 'Oh! oh!' I thought, 'here is a devil.' I was not scared, because I had been well instructed how to behare under such circumstances. I went to it and passed my hand all over its body. The nativcs who know about it," he remarked, "always do so; and if you do, the devil will not harm you. I touched it all over; it was cold and quite hairy. When I touched the arm-pit, he began to chuckle. I stopped one moment and . . . it was gone. I did not see it any more. I struck a match and looked in the corners of the shed: nothing. Then I went in, and told the others about it. 'Oh! yes,' they said, 'we see him often. He is quite a customer around here.' In the same place," he went cn to say, "there lived a man who was frequently invaded by a devil. Once we were about twenty persons, squatting around in the cabin. He was among us. Suddenly he stood up, unbuttoned his trousers and drawers, and his belly swelled to enormous proportions. Then he began to tell us many secret things, that were perfectly true, but were known only to a few of us, so that he made many ashamed of themselves. But no one dared to reply, 
because we all knew that the devil was in him. He was several hours in that condition, after which he began to feel very thirsty. In a short while he drank up all the water that was in the house. In the corner, there was a pretty large tub, one half of a large barrel which had been sawed in two. This had been used, according to the custom prevalent in that place, as a chamber-pot. It had not been emptied for months and had a terrible stench. Well, you wouldn't believe it, but I saw it: he drank it all, to the very last drop, and then the devil left him." He continued: "The poor man died some years after, whilst the devil was in him. I was there and saw it too. His belly was so swollen that they could not fold up his legs, to bury him in the ordinary position" (that of the child in the mother's womb); "so they remained half-stretched. He was so heavy that no two men could move him. They tied him to a pole just about the size of this stove-pipe" (it was 7 inches in diameter), " then four men got hold of each end, and the eight of them carrying the pole on their shoulders began to move, with great difficulty, towards the burying ground. But, before they reached it, the pole broke suddenly, though it was a tough green spruce, and the body fell so heavily that it sank into the ground and made a grave for itself. We lined it with birch bark, pushing it down with sticks, for no one would venture to go down in the hole, although it was large enough. Then we heaped logs and stones over it. It is still there: anybody can show it to you, if you go to that place."

These instances will be sufficient to show in what sort of an intellectual atmosphere the Ten'a live. Thus one may better understand how they really believe the tales of the medicine-man, and what sort of an influence he exercises over them.

To return, then, to the religious or philosophical notions of the Ten'a.

They believe in the existence of numerous devils, spirits, indeed, but with a sort of an aërial body, not of the same matter as our own bodies, but, as it were, something intermediate between body and soul. They are termed, in general, tsonteye, evidently from tso-neta-yc, the evil thing, or nekedzaltara (nekedzalta'ha), a word which could be rendered as the swifts or the quick-movers, the prefix dzct with the root tar (ta'h) being used to signify dances and quick motions.

These spirits are essentially malignant, and their sole purpose is to do harm. There is a sort of a hierarchy or subordination among them, the most powerful being always spoken of as tsonteye, never as nekedzaltara, but the inferior being indifferently designated by either name.

Some spirits minister to men, mostly to help them in doing evil, but cocasionally also to provide for them the necessaries of life. Even in this, however, the spirit's intention is to do harm, viz., to the enemies of the one whom he helps. They do not actually suppose that the spirits help men, but that men, who have power to command the spirits, by this means may help other men.

A spirit, considered in his capacity of familiar demon or being ministering to a man is called sen, a root-word which seems to have no other meaning, or also, 
atta, attaa, which seems to mean a male, for the root-suffix tta properly means male, as appears in ranölta (hanōlta) a male-deer, a buck, from ranōya ('hanōya) a deer; tintta, a male-dog, from tik, dog, etc. These words are used mostly among the adepts, the common people, in ordinary circumstances, use the term nekedzaltara.

A man or woman, who has at his or her command one of these familiar spirits, is a medicine-man or a medicine-woman, as the case may be. The Indian word for these is teyen, a shortened form of teyenen, the one who bewitches or conjures, from the verb: eseyen, I witch or conjure. They are also called kōtni, kotniye, the teller, the one that tells. The Russians designated them by the word shaman, which, according to Ivan Petrof, is " a Kamchatkan term for sorcerer or medicineman, used by many tribes who once were subject to Russian influence" (The Population and Resources of Alaska, 1880 ; printed in the Compilation of Narratives of Explorations in Alaska; Washington: Government Printing Office, 1900, p. 108). This appellation is not uncommonly used by travellers and explorers.

There are undoubtedly more inedicine-men than women, and I would estimate the proportion to be one medicine-woman for every five medicine-men. Both sexes, however, are equally admissible to the profession, and it should be understood in what follows that what is said of medicine-men applies equally to medicine-women.

Whether a medicine-man can have at his command more than one spirit is a question which I cannot presently answer. I can only say that I never heard of a single instance of the case. It is admitted commonly, though, that, by means of his one spirit, a medicine-man can muster up a few others, to perform some unusual task. An instance of this kind is on record, and this is the legend of the formation of the Kayar (Kaya'h) Slough. ${ }^{1}$ The legend runs thus:--The Kayar Indians, once a numerous tribe and having powerful medicine-men, were getting tired of portaging their canoes through lakes and marshes whenever they would come to the Yukon. They requested their medicine-men to have a channel dug for the purpose, which would connect the Kayar settlements, by an all-water route, to the Yukon River. Whereupon three of those worthies joined together, at a place called Tartsenibanten, on an island of the Yukon River, about 20 miles below the actual site of Nulato, and, having gathered the people in one house, charged them not to leave the place nor to look at what was going on, until they would give them leave to do so; for the spirits to be summoned for the purpose were of the highest order, and any profane person, even if he only saw them for a moment,

I In this local meaning, the word slough, pronounced slōo, designates a side channel or inlet from a river. It is used throughout Alaska, where such sloughs are numerous. The Kayar Slough is ineorrectly represented, on all the maps I have seen, as two small rivers, the one emptying irito the Yukon, about mid-way between Nulato and Kaltag, which bears no name on the map of 1904, is really the entrance or inlet of the slough; the other emptying into the Yukon below Kaltag, called Kaiyuk River on the same map, is properly the outlet or mouth of the slough. There is a small river, the Rotolno ('Hotolno) emptying into the slough at its northernmost turn. 
was sure to die. Then they set to work and began the incantations. Seven spirits were detached for the expedition. They started from a point opposite to the island, on the south bank, and began to make their way to Kayar, swallowing up the ground as they passed, and a mighty crooked way it was, too, as the interminable winding of the Slough shows up to this day. In a few hours they had joined the Rotolno, and the Yukon rushed its waters through the new channel, towards the Rotolno, making a sharp bend at the junction, and thence flowing down with the peaceful Rotolno, to the lower mouth. When the task was achieved, the seven spirits were tired, and lay down to rest for a while. Whilst they were sleeping, two young men, who were not aware of the presence of these high personages, came down the Rotolno in their canoes. The one who was paddling ahead came unexpectedly at the turn and beheld the frightful sight. He uttered a loud shriek, stood up in his canoe, and dropped dead. His companion saw this, though he could not yet see the awful monsters and it was his good luck that he did not see them. Warned by the fate of the other man, he made for the bank and lurked under the brush for a couple of days, after which he saw the people coming in their canoes from Tartsenibanten, who told him of what had happened. Nothing was ever found of the unfortunate fellow who had with mortal eyes gazed upon the seven spirits.

The same legend, with some difference in the details, is current about another slough, opposite the mouth of the Koyukuk River. In this case, however, the medicine-men were many, and the spirits, who performed the task, only two. The slough is much larger than that of Kayar, being, in fact, practically the main channel of the Yukon. But the very configuration of the river countenances the native tradition, that the main channel was formerly the northern one, and that the actual southern one is of a comparatively recent date. ${ }^{1}$

The social standing of a medicine-man is, on the whole, a desirable one; but it has also its drawbacks and its dark side. The medicine-man is decidedly influential among his fellow savages. He is consulted and listened to, on account of the superior knowledge imparted to him by the spirits. He is feared, on account of his power to do evil, viz., to cause the death of a person, to ruin his undertakings, to render him unsuccessful in the hunt by driving away the game from his path, to cause the loss of his property, of his strength, of his health, of his faculties, etc. The medicine-man is rich, because his services, when summoned, or even when accepted though uncalled for, are generously remunerated. He is respected on account of his continual intercourse with the supernatural world. His words, when said in a peculiar low tone, with a momentary glow in the eyes, which seems able to control at will, or when uttered during his sleep (real or feigned), are taken as oracles, as the very words of the spirit. In short, for these tribes who have no chiefs, no religion, no medical knowledge, he is the nearest approach to a chief, a priest, and a physician : to a chief, because he practically forms and models the public opinion, the only rule among Ten'a, to a priest, because

i It is to be regretted, indeed, that these medicine-men are not hired by the Panama Canal companies: there would be a great saving of time and money. 
he acts as the intermediary between the visible and the invisible world, to a physician, because his power enables him to cast away devils by which diseases are caused.

One ought to add that all diseases, according to Ten'a medicine, originate in a spirit locating himself in a person's body. The medicine-man, having a devil at his service, may, by means of it, expel the intruding spirit, provided, of course, that his own demon be more powerful than the intruder. If the reverse happens, he fails in his attempts to cure the sick person, and incurs no odium by the fact. It is not his fault, if his spirit is not stronger than the opposing one, and he is not made responsible for it.

It is readily acknowledged that every individual spirit has but a limited power, and this accounts for the superiority of certain medicine-men over others: it is all owing to the superiority of their spirits. And when it happens that two medicine-men are enemies of each other, the one who has the stronger spirit is sure to triumph over his opponent sooner or later. But this is a great source of mischief to the relatives of a medicine-man. If he happen to be at odds with another, each spirit working zealously for his own man, the darts, so to speak, which are sent by one spirit may be averted by the other, but if this other spirit is not very powerful he will only turn aside the infernal darts, which will strike the relatives of the medicine-man, leaving him unhurt. I had an instance of this in the spring of 1905, when one of the Kaltag Indians, Ignatius Kayinel'an, commonly known as "Big William," was accidentally shot by one of his companions on the hunt. As he did not die immediately, I was called upon for medical assistance and went to Kaltag, but found him already dead. His brother-in-law, amidst his lamentations, addressing me, said: "Why is it that there are still medicine-men living among us?" As I failed to see the connection, I enquired why he said so. "Don't you see?" he replied; "two of his uncles are medicinemen, and they have many enemies. Now some of these, being medicine-men themselves, are trying to kill the uncles. But these uncles are protected by their own spirits, and the evil directed against them falls on their relatives. This is how this man died. Yes," he emphasized, "the medicine-men are very bad, and we have no use for them!"

This is, in truth, the objectionable side in the condition of a medicine-man. $\mathrm{He}$ is influential, feared, respected to a certain extent, receives abundant gifts from his fellow natives, but he is not loved, nay, he is strongly disliked. He may win the gratitude of patients who believe they have been cured by him; but he is always considered a dangerous person, who may at any time turn against his best friends and cause their death, either willingly and by witchcraft, or even unwillingly by the inadequate protection of his spirit. He is aware of this feeling, too, and though he generally disregards it, it weighs at times beavily upon him. He then wishes that he had never become a sorcerer. But it is too late; to renounce bis profession, he would need courage enough to withstand tle general discontent of the people, who, though they dislike the sorcerer, firmly 
believe that they are in need of his services. To them he is a necessary evil. To abdicate would be to incur the popular disgrace, and there are few Ten'a who have the strength to do so.

As has been said, the medicine-man does not choose his own spirit, but he is chosen by him. There is a vocation, a devilish calling to the craft, which one may disregard but cannot make for oneself-at least, according to the Ten'a notions. Some, indeed, are naturally predisposed to the calling. A peculiar deformity, which singles a man out of the vulgar crowd, is a sign of vocation. Thus the cross-eyed, the cripple, the lame, the sterile women, are more apt than others to be called to the devil-craft. Thus, for instance, Tirénka (Ti'henka), a famous shaman of the Kayar Indians, mentioned by Dall (Alaska and its Resources, p. 205) under the name of Tékunka, had a sort of an appendix, probably a superficially located cyst, about the size and the form of the thumb, hanging from his breast. Several whom I knew were cripples, and the two medicine-women with whom I am well acquainted are sterile.

The calling to the profession is by the finding of a karunit (ka'hunih), which invariably happens in this way. The predestined individual, as yet unaware of his election, has a dream. The circumstances seen in the dream may vary. To some the dream will picture their roaming in the woods and finding the karunih; to others, it will be likervise a walking through the forest and meeting a nice-looking boy, who will ask them whether they would be glad to possess præternatural powers, or some similar happening. The next day, the dreamer, generally filled with hopes and excitement, starts rambling through the woods. If he sees an animal, he will pursue it, but he will be led by circumstances, which do not depend on him, to a place which he recognises at once as the one he has seen in his dream. He looks around; perhaps the same boy who spoke to him in the dream will be there to help him; anyhow, without much effort, he notices, at the foot of a large tree, a blue flame covering a round space about the size of a common plate, say eight inches in diameter. He draws near, and there he beholds the karunih, small round bodies like beads, of the size of salmon-eggs, i.e., about as big as a pea. They are of all colours, from twelve to twenty in number, very seldom more, their number being in proportion of the power of the connected devil. They seem to be alive, moving and dancing in a circle around the blue flame, passing again and again before his fascinated eyes. He generally hesitates for a long while ; for there is nothing more irresolute than a Ten'a, and he knows that it lies within him now to answer or not the call to the spirit's friendship. He may leave them and go his way; and $I$ know one who boasts of having done so. Generally, though, he is glad of the find, and determines to pick it up. He takes the first bead that he can catch, lays it on the palm of his left hand, applies the tip of his right fore-finger on it, and, making a strong act of his will-or imagination-he wishes for a certain specifled power connected with it, saying, for instance, to himself, "This will give me the power to call the game and bring good luck on the hunt." He then looks for a sign that his wish is granted. 
If he sees, for instance, an animal coming out from the woods, be it a rabbit, a grouse, or even a vulgar mouse, he knows thereby that he has his wish. He then puts back the grain and picks up another, which he holds in the same way, saying, perhaps, "This will give me power for calling or sending away devils." Whereupon a mysterious shiver passes through his whole frame, and he becomes aware that he has the desired faculty, and thus he proceeds to wish over each and every one of them. If some wish is not granted, the warning of acknowledgment fails to come; then he has to hold the bead and try another wish, until he strikes the right one. The reason of this is that not all spirits have all powers, and, according to sound philosophy, no one can grant what he has not. He may happen to wish for things which are beyond the power of the particular spirit with whom he is contracting. These are not granted, of course, and he must hit on the proper ones. There should be but little difficulty in this, because the cycle of wishes is always about the same. When he has passed all the grains over, he gathers them all and places them carefully in a small skin pouch, or, in our civilised days, in a small brass box, generally an empty box of Winchester primers. He now carries the amulet around with him; he does not fear the loss of it, for he knows that, if it happened to be lost or stolen, it would find its way back to his pocket without any more effort than a wish on his part. $\mathrm{He}$ is a medicineman.

Such is the ceremony of investiture. As may be noticed, it is not done by mortal hand. It is all under the immediate guidance of the spirit, and one must acknowledge that for rude savages the fake is a good one, well combined and ingeniously put up. A spirit is attached to, literally tied to (ro tadlerun) the karunih, and this becomes the familiar spirit of the new medicine-man. The man generally does not see him. The spirit may have good reasons to abscond, as had the veiled prophet of Khorassan ; but the fact is, that the medicine-man, without seeing him, is aware of his presence and feels the benefits of his protection.

When he needs to exercise his supernatural powers, the shaman takes from the pouch or the box (in a solitary place away from the indiscreet looks of the profane), the karunith which is fit for the purpose. He.must know them all individually, and remember their destination, or else he runs the risk of a conspicuous failure. He drops it into a cup of water and swallows it. Never mind where it goes, it will be found again in the box, as soon as desired, and while the karunih is in him he will perform as a full-fledged priest.

As to the word karunih, it applies to the whole collection as well as to each grain in particular. Ten'a words, unless they designate persons, have no special form for the plural ; the verb that governs them only changes its form. Hence, when one grain is meant the form for a singular object is used, with the same word karunih; when the whole collection is spoken of, the form for a plural object is used, the word karunih remaining the same. The etymology of the word is very obscure to me. The root nih which seems to be the main part of it, has a very general meaning, signifying action or power. 
Although a medicine-man, as such, is considered to be above the common people, his ordinary life and his daily occupations in no wise differ from those of his fellow tribesmen. He hunts and traps, fishes, chops wood, works, just as they do. The consequence is, that by these means he earns as good a living as any other Ten'a. He does even better, on this score, than the average of them, because he is generally smarter. With what accrues to this from the exercise of his preternatural powers he has always plenty. His gains from this source always come to him as gifts. An Indian, it is true, never gives but to receive, and an Indian gift always turns out to be a contractus in nominatus of the kinds do ut des or do ut facias. But the medicine-nan never requires anything as pay or salary for his services. He renders his services only after having received a gift, but it is a gift, and a gift it must be. The action of making a present to the medicine-man to secure his help is expressed by a special word uskün, derived from the root kün, fire, and which would mean literally, I set fire to, I burn. A few examples will sufficiently illustrate the process, and offer a general view of the shaman's work. The most common occurrences are the foretelling of future events and the healing of diseased persons. The former is always at the disposal of the greedy and covetous sorcerer, and these are the majority; the latter is accepted by any shaman when the opportunity offers.

To work out some profit from his knowledge of future events, a shaman generally proceeds in this way.

He takes notice that one or other of his neighbours and friends is in possession of some desirable article, as a fine blanket, or a valuable gun, or a new cooking stove. He comes to the owner, or to some of his relatives whom he knows to be thorough believers, and confidentially lets out that he has had sad intelligence communicated to him, concerning the said person, and this he discloses, as it were, reluctantly; the unfortunate man is doomed to die within a certain space of time, say, for instance, before the next spring. Others indeed will go at it in a brutal way, and say that they will make him die before the spring. But this rough way of dealing with the matter is exceptional. The news, of course, brings great consternation to the whole family, to whom it is speedily imparted. The person concerned begins to think of some valuable present to offer to the sorcerer, that he may avert the impending calamity. He generally chooses the best thing he has, and is pretty sure to hit on the coveted object, which being offered to the medicine-man and accepted by him, will set all things aright. In consideration of this gift-for it gues under no other title-the shaman will either perform solemn incantations, or, by a mere act of his will, commission his familiar spirit to save the threatened life. The doomed one does not die, the power of the great medicine-man is enhanced, and he is liable to receive more gifts from other members of the family, as tokens of their gratefulness for his valuable assistance. As one can see, the process is simple enough, and it works admirably on the credulous and timid Ten'a.

Similar dealings have been attributed to sorcerers of the Hawaiian Islands, with this peculiar feature, however, that the mediciue-men of those Islands are 
skilled in the manufacture of poisons, by which they contrive to bring about the fulfilment of their predictions. The Ten'a fully believe that their own shamans can obtain the same result by means of their devils. But there is no one fact known to me that would offer a ground to the supposition that they can poison their victims. It may have been the case in olden times, but nowadays, as far as I know, they have no knowledge of poisons nor of any way of preparing them. Moreover, if it happens-and the case begins to be not uncommon-that the person whose death is announced disbelieves the prediction, it remains without effect. I have seen two notable instances of this. The one happened last winter, at Koyukuk Station twenty miles above Nulato. An Indian woman, married to a white man who is trading at this post, was the object of such a prediction. She and her relatives were in great anxiety, but the white man, whose consent she knew was needed to dispose of her or his property, absolutely refused to gratify the medicineman's impudence. She fell sick, no doubt from the fright, and I was called upon to interfere and encourage her failing spirits. She finally was persuaded to try and overcume her fear; the fatal period passed and though rather unwell, she is still alive.

The other instance took place in the winter of 1901. A native, who claims to be a half-breed Russian, though I am convinced he is a full-blood Ten'a who was only adopted by a Russian convict, was living at a small village called Koyékasten, some twelve miles above Nulato. A medicine-man came down from the Koyukuk River, and made to him the dreadful disclosure that he would surely die before the ice would break on the Yukon. "Hold on !" said the other, "do you know to whom you are talking? I am the son of a white man, and you have no business to tell me such nousense. I know what this means. You are after my new blanket, but you won't get it, and I won't die either." The shaman went away, shaking his head in an ominous manner, and refused to say a word more on the subject, although the relatives were anxious to hear some particulars. The wife of the doomed man was the most affected, but he stood it bravely. Of course he neither died nor even fell sick, and during the winter of 1902 he was relating the fact to me, in presence of many who had witnessed it, and triumphantly added: "Here now I am, as hale and hearty as ever. It is one year since that happened : I am not dead, and I still have my blanket." This man's name is René Koltsik, and, if he is not a half-breed, he is surely worthy to be reckoned as one.

During the spring of the same year, 1902, I witnessed another instance of disbelief in the shaman's foreknowledge which it may not be uninteresting to quote. I was spending a week in the same village, Koyékasten, lodging, as all travellers do, in the house of a native. My host was a simple-minded, good-natured fellow, who two years later shot himself in a fit of discouragement or insanity. His wife, much older than he, was the ruling power, not only in the house but also in the village, and still is very influential in the upper tribe. She is an ex-medicine woman, formerly held in great repute as such, who had given up the profession in order to become a member of the Church. After a long probation 
I had finally admitted her to the Sacraments some days before. She had therefore two reasons to disbelieve: the one, her newly professed faith, and the other, her knowledge, personal and experimental, that the whole shamanship is an imposition. They were both, husband and wife, busily engaged in completing their preparations for the spring hunt, polishing guns, loading shells, sewing a tent, etc. An old medicine-man, Kapsul, entered, and, as customary with travellers and passers-by was welcomed with a substantial lunch. When he had finished, he said a fer words, which I did not understand, in a low tone and departed. My host and his wife looked at each other, as in surprise, for half a minute, then the woman began to laugh. Cicero has observed, of old, that one could hardly see how haruspices could look at each other without laughing. She said to me: "Did you notice his last words?" "No," said I. "Well," she replied, "he made a prediction. He said that we would not go to hunt this spring." "And what of it?" I enquired. "It means," she went on, " that either we shall be prevented by some accident, or at least that we will be unsuccessful." "What are you going to do ?" I insisted. "Oh!" said the woman, "I know all about that! We shall start in two days, and be as successful as we usually are, God so willing. I know about it, believe me." They went and made a good catch, so good that she was in a hurry to inform me of it, and as soon as they reached a telegraph station, on their way back, she sent me a message stating that they had killed five deer, seven heavers: and I don't know what else.

Such instances as these are by no means the common rule, and to each of the above mentioned I might oppose about twenty in which the Ten'a credulity paid a generous tribute to the medicine-man and his devils.

The healing of the sick is the other ordinary source of revenue to the shaman. He does it in various ways. He may just take a cup of water, blow into it, and give it to the patient to drink, who feels instantly relieved. A case of this kind happened in the latter part of the winter of 1905 , at a village situated six miles below Nulato, and known as Nikulikakat. A young woman, Olga Kats, a primipara, was in the pains of labour. As these were unusually severe, she sent to Nulato for some medicine, which I gave to the messenger, instructing him how she should use it. She did so, but as the result was not instantaneous, accounted it null, and called in the medicine-man. He gave her a cup of water to drink in which lie had blown, and immediately she was delivered. When she related to me the fact, I felt almost sorry that I had given her anything at all, but I could never persuade her that the first medicine had contributed more than the second to the desired result.

The solemn performance is much more showy, and well calculated to inpress the imagination of the natives, who, whenever they are under an excitement, get altogether out of their wits.

The medicine-man is not generally asked to perform. The invitation or suggestion is done covertly, in a mysterious and indirect way. A relative, or a parent, of the sick person goes to visit the shaman. He brings along with him 
a present of some kind, say a sack of flour, or a beaver skin, or a blanket, which, upon entering the house or tent, he lays in a corner. He then proceeds to converse on commonplace topics, which he brings gradually to bear on the sick person's condition. This he describes with all particulars, generally with colossal exaggerations, equally emphasizing his own grief over the sufferer's ailments. When this is done conscientiously, and perhaps many times repeated over and again, he waits for the oracle. The medicine-man may answer simply that nothing should be feared, that the disease will not prove fatal, and send him back reassured. In this case he is supposed to work the cure without more ado, by an act of his will, directing his spirit to do the job. Of course, he keeps the present; though, if the patient should die, he would be bound in strict duty to restore it, or its value, to the one who.offered it. These people being constantly sick, all the year round, from one complaint or another, this simplified process has to be frequently adopted, for a too frequent repetition of the grand incantations would be exhaustive to the medicine-man and probably also weaken the faith of the believers: $a b$ assuetis non fit passio, as the scholastic philosophers say.

Or, again, the shaman may think it proper to give the full performance. If so, he warns the one who has prompted it (by giving the present) that the case is a difficult one, and that he will have to go and attend to it himself. The time is appointed generally for that very evening, and all the village is informed, one person by the other, in mysterious undertones, that the incantation is about to take place. A sort of awe pervades the place. A supernatural influence seems already to hang over it.

When the time is come, the believers, one after another, repair to the sick man's house. They do not walk to it openly, but stealthily, as it were, singly or two at a time; neither do they go in many at once, but few at a time. When a sufficient quorum is gathered the medicine-man sets to work.

For what follows, I feel bound to declare, though it may be of little moment, that I have never been an eye-witness of the scene. No medicineman that I know of would venture to perform in presence of the priest. But the Rev. Father Ragaru, in the early years of his stay at Nulato, once had an opportunity to gaze at the scene, whilst standing on the outside by an open window. It is mainly from his description, together with a few details supplied by natives themselves, that I have drawn up the sketch.

The patient is laid upon a bed, in a corner. The audience are squatting all around, along the walls of the cabin. The medicine-man is in the middle. They begin, the shaman leading, to hum a plaintive tune, the voices being gradually raised to a louder, but not very loud, utterance. After a few minutes, the medicine-man, covering himself over the head and shoulders with a blanket, begins a sort of dance, keeping time with the tune, which he sings all along, his voice practically covering the humming of the audience, which sounds as a sort of an echo to it. His motions, slow at first, graaually become quicker until he works himself to a regular mad dance. Perspiration runs freely over his whole body, his 
face, distorted by effort, assumes a hideous appearance, saliva drops from his mouth, and his voice, tired by the continuous yelling, becomes hoarse. Needless to say, the excitement of the assistants is not a whit less than his own, and only the greater because it is kept under control. The patient has to be very sick indeed if he does not feel the influence, and if his imagination and credulity are not roused to the utmost. This may go on for one, two, or even three hours. Finally, when the shaman thinks that enongh has been done in the way of incantations, he makes more and more frequent stops at the bed-side, pretending to make great efforts at extracting something from the patient's body. Once, twice, three times, perhaps, he fails in his attempt. The sick man groans with pain under the squeezing hand. The medicine-man exhorts the assistants to further efforts; the music of the chorus redoubles its plaintive accents, and eventually the spirit has to yield. The sorcerer, by a supreme effort, has extracted the spirit. He holds it with great effort between his closed hands, and goes along the row of the beholders, putting to them the uncanny question: "Is there anyone who will volunteer to take this spirit into himself, and thus save this poor man's life? Who will do it? Will you? or you?" etc. They all shrink from the task, and a dreadful silence is the only reply. He has then two ways of disposing of the weird burden. He may say: "There is no one! no, not one! Then I take it myself : let it come in my body and work evil to me. I shall save my friend, even at the risk of my life!" Whereupon he generously applies both his hands to his chest, and gets the spirit into himself. A noble deed, which is bound to deserve the grateful admiration of all present! But he will not always play this grand scene. More often he simply throws the spirit into the fire, or outside, through the door or window. This was the way it went when Father Ragaru was watching the performance. The sorcerer came to the window to despatch his captive spirit into the aerial spaces, when he unexpectedly beheld the missionary's head laughing at him through the window. He lost all self-control : "The priest! the priest!" he exclaimed. An indescribable confusion followed. The lights were put out, and the audience skedaddled in all directions, as though the real spirit had carried them along.

After the performance, both the doctor and the patient generally need rest. If the latter is at all curable by this method, he ought to begin to get better. In the cases which came to my knowledge, however, I may say that the patient generally felt much worse on the day following. If he fail to recover, the medicine-man is expected to return the gift he has received, for it was not given him to attempt the cure, but to effect it. This practice is so constant, that the Ten'a, at first, expected that the white physicians would conform to it. An American physician, Dr. W. Jennings, who wintered at Nulato in 1898-1899, used to attend to the natives during his stay. He rendered his services free of charge, whenever I assured him that the persons concerned were poor and unable to pay, but requested a fee of $\$ 5$ from those whom I pointed out as able to bear the expense. Once he treated the child of a native medicine-man for typhoid fever, 
but, in spite of his effort to save her, the girl died. Her father expected to get back his $\$ 5$, and came to me for the purpose. As he is, however, a sensible fellow, we had not much trouble in making him understand that the white man's doctor works on a different principle from that which guides the Ten'a, and he willingly waived the claim.

A medicine-man who has cured a sick person generally imposes on him an abstinence of some kind, which may be temporary or last his lifetime. It will be, for instance, to abstain from anything hot, eating and drinking only cold or cooled food and beverage, or to abstain from a certain kind of fish or meat, etc. These are scrupulously observed. There was at Nulato a young strapping fellow, whom I frequently hired for work whilst building the school-house in 1899-1900. He was called Neraila (Ne'haila), a corruption, I understand, of the Russian form of Michael. He had been once cured of some complaint by a medicine-man, and consequently had been enjoined to abstain from a peculiar kind of fish, very palatable indeed, which the natives call telebèga. As we had to feed our workmen, and teleberga was plentiful, the Brother in charge of the kitchen generally gave them a dish of telebèga for supper. Neraila would never touch it. His companions, some of them strongly inclined to disbelief, as young men mostly are now, laughed at it, and mocked him. But nothing shook his constancy. At last the kind-hearted Brother took pity on hin, and cooked a separate dish for the man when he had to give the forbidden fish $t$ s the others. Poor Neraila did not have to wait very long, however, to be freed from his obligation, as death released him during the summer of 1900 . It is easy to understand that, by this practice, the medicine-man obtains a stronger hold on the minds of the people. They are thus trained to the habit of obeying him and following his directions. Even those who have no such restriction imposed on themselves, if they see others bound by them and keeping them carefully, get accustomed to the idea, and consider it as a matter of course that it should be so.

Besides these common practices, which are still kept up by the medicinemen, they had, in former years, other occasions to display their powers for the benefit of their fellow-men, and their own. Some have fallen or are falling into disuse. I shall mention, however, the calling of fish, and the performance of wonderful tricks, as these are now one of the most ordinary topics of conversation among the Ten'a.

Of the first, i.e., the practice of calling the fish or the game, something is still kept. Even now there are few Ten'a who will start on a long hunt, or set to work during the salmon run, without giving a bribe to the medicine-man, or at least promising him a tithe or commission on the catch. The sorcerer has not to perform any extraordinary conjuration, but just directs his spirit to give help, and if the catch is good, obtains a goodly addition to what he may get himself by his own exertions, thanks to the spirit.

Whether there existed in by-gone days a regular process for calling the game, I am not aware, but such a practice uniformly prevailed for the fish to 
be called to run at the regular time. Many have described to me the performance, some claiming to have been eye-witnesses of it. They invariably add that the shamans of this day have no power to compare with those of the past, and it would seem as though the old superstition was near to die out. One can detect in this a feeling of impotence, which tries to keep to old traditions in order to assume some appearance of power and strength. They cannot fail to realise that the medicine-man's doings will not stand a severe scrutiny; they see the whites turning the whole fake to ridicule; they hear what we all have to say about it, and, giving it up, as it were, for a desperate case, they fall back on the past times, about which they relate all that their imagination suggests, there being no contradictory evidence that can be produced. It is not to be supposed, however, that they are conscious of their lying in this matter. Their mental condition is similar to that of one of those convinced "hot-air peddlers," as the miners call them, who after having repeatedly gone over the same wonderful adventure, finally come to believe in it themselves.

The calling of the fish, then, is thus described by the Ten'a. Towards the spring the people began to feel anxious for the next summer's run. The provision of dried salmon from the preceding year beginning to fail, they were desirous of having a good catch during the coming season. The medicine-man was at hand. Having sufficiently prepared the people's mind, by much talking and discussing the eventualities of the forthcoming salmon run, he gathered all the folks in one large cabin, chosen for the purpose; he commanded tliem to keep a Ten'a wake in the place, no one being allowed to leave it, even momentarily, until his return. If any person would presume to do so, it was sure to cause the shaman's death; and, subsequently, his own life would be lost. The sorcerer then dressed up, for lie had a long journey to accomplish, under the waters, within the short lapse of one night. He put on a parkie, the native jacket, not open in front, made of the guts of the beluga or white whale, perfectly water-proof, pants equally water-proof, made of seal-skin submitted to a special tanning process (with ashes), and boots of the same material. These boots, commonly known as "water-boots" in this district, are still in use among the Ten'a, and the whites have adopted them also, on account of their standard qualities. The two other articles are no longer used by these people. The hood of the parkie being fastened tightly around his face, and the parkie itself well secured ly a belt of raw hide, he put on his mittens, and having renewed his warnings to the people, he descended the slope to the river, escorted by two assistants, whose privilege it was to help him in getting in and out of the water.

The water-hole, an opening in the siver ice from which the native women daily get their fresh-water supply during the winter months, had been eularged for the occasion, so as to allow a man room enough to get in. It was to be the starting point for the shaman's trip. Into it he descended, with the aid of his faithful seconds, and they, well clad to stand the crisp cold of an Arctic winter 
night, had to keep watch at the hole, waiting for his return. Meanwhile, he was travelling at a ghost-like rate to the place where the salmon, in large bands, were spending their winter. Many a wonderful sight did he see in these excursions, many a thing hidden from the profane did he learn in his conversations with the dumb inhabitants of the deep. He treasured up information of all kinds, knowledge and wisdom were imparted to him; so much, indeed, that several times, when I was trying to argue with some native over the Ten'a superstitions, and he was brought to bay, he finally had recourse to this answer: "All those reasons may be satisfactory for you, who know only what is written and printed in the books; but our medicine-men know much more than that. They go under water and talk to the fish. There it is that they acquire the knowledge of these things which you cannot know because they are not written." To such a convincing reason there is, of course, no reply. Towards the dawn of day the medicine-man came back. He climbed out of the hole, the assistants having been careful to prevent its freezing by removing the new surface-ice as soon as it formed. He was thoroughly soaked, very cold and very tired. He was taken up to the cabin for refreshments, told of the success of his embassy to the powers of the fish kingdom, and received not only congratulations, but more substantial evidences of the general satisfaction. The assistants had also a share in the presents, and this may account for their never letting out any indiscreet revelation that might have brought suspicion on the genuineness of the venture. Nowadays, however, the shaman no longer goes to call the salmon, and still these well-meaning fish continue to swim up the rivers every year, as well as if they responded to the yearly invitation. We should draw an inference of no small moment from this fact; a Ten'a won't.

As a display of power, without any particular purpose, but always sure to be repaid by a shower of presents, the medicine-men used also, in former times, to indulge occasionally in exhibitions of wonderful feats, such as any sleight-ofhand performer accomplishes to amuse an audience. The practice having fallen into disuse, I am limited to the people's traditions for my information, and everybody who knows the Ten'a is bound to consider it a very questionable source. A few instances may prove to be of interest.

A shaman of Rodokakat ('Hodokakat) was wont to fly in the air, as often and as long as he wished, on the condition that no woman saw him whilst he was on the wing. If one had looked at him he would have gone out of sight, far beyond the clouds, never to see again his native country. This he barely escaped once when a woman, who had not been warned that the gentleman was in his aeronautics, happened to come out of her house and to look up to the sky: There she beheld him, and the sudden upward start which he made was enough to warn her of the peril. She closed her eyes, stepped back into the cabin, and it was-not till after a long while that the sorcerer came, through what herculean efforts one may easily.imagine. I had these facts from the shaman's 
son, Nicholas Surarlol (Su'ha'htoł), a man now about forty-five years of age. $\mathrm{He}$ was a small boy still when his father died.

A certain medicine-man at Kodilkakat, on the Koyukuk River, used to put aside his head, before falling into a trance, during which he held intercourse with the spirit world. I would venture to suppose that the bystanders lost theirs rather than he. His apparatus consisted of two spruce trees, which had grown close to each other, there being, perhaps, a distance of eight feet between the two; they were about forty feet high. He gave orders to the people to lop them, sparing only a bunch of boughs at the top of each. Such lopped trees are still used among Ten'a to mark the site of a graveyard, a village, etc., because a traveller can notice them from afar. At the top of these, just below the branches, a cross-piece was fastened from one tree to the other, over which passed a long strip of raw hide, long enough to hang to the ground on both sides. One end of this he tied into a slip-knot, and inserted his head in the noose. Four or five men pulled the other end and thus hoisted him up to the cross-piece, where he hung in the air. The rope was made fast at the foot of a tree, and, while the believers were gazing in awe at the ugly sight, the body was severed from the head and fell to the ground, the head remaining at the top of the structure. The senseless, headless body would lie on the ground for several hours together. His soul was then journeying in spirit-land. It all ended by the head falling down too, and reuniting itself to the body so perfectly that no trace of the separation could be seen. He had a tragical end, for he never came to from one of his trances. In vain did his admirers wait for the reviving to take place; it failed to occur on this particular occasion, and they had to bury him, in two pieces, head and body disjoined. Hence he is now spoken of as "the one whom we hanged," mel ketsettkelen. Fifteen or twenty years ago anybody could have pointed out the two trees, which were still standing at Kodilkakat. Now they have disappeared.

Other shows could be commemorated here, but hardly deserve more than a passing mention. Shamans allowed themselves to be shot at with a rifle (which they themselves had loaded, or allowed another man to load), dropping down as dead and afterwards jumping to their feet, making an infuriated run, and finally coughing and spitting out the bullet. Others covered an empty dish-pan. with a piece of drill, raised it toward heaven, and when they put it down it was found filled with powder or shot or gun caps. Another one took the stars from the sky and laid them on the floor of the cabin before his wondering admirers. He must have been very careful to put each back in its own place, unless, perhaps, he be the one who is answerable for the loss of one of the Pleiades.

If there be any truth in these facts, they would prove that the medicine-men in the old times were skilful performers, a qualification which their actual successors lack conspicuously.

There is also on record a famous prophecy set forth by a medicine-woman from Tozikakat, a camp about seven miles below Tanana. She predicted the 
coming of steamers, some fifteen years before any had come to this country, and announced the coming of missionaries, giving a summary of the "law of heaven," which they were to proclaim. But this prophecy does not stand examination, and the first investigations show it to have been made up after its accomplishment. It is just possible, however, that the coming of steamers, and even of missionaries, would have been foretold by kome of the whites who came to the country with the telegraph exploration party in 1867 , the prophecy being assignable to that time or thereabout.

With such and similar predictions, the medicine-men obtain a very creditable reputation among their fellow Indians. Of course they are liable, as any other Ten'a, to experience a foreboding of some kind, when, for instance, strangers or travellers are to arrive, when game is to be caught, etc. But these forewarnings, which generally consist in an unusual sensation, as an itching of the forehead or leg, etc., or a sncezing, or swallowing particles of food in the windpipe, are an everyday occurrence, by no means restricted to medicine-men, but happening also to old women, or in fact to anybody. They are not therefore within the scope of this sketch.

It might be enquired, now, what sort of lives the medicine-men live, with so much devilry about them. To this I can reply that, in their private lives, they are neither worse nor better than the average Ten'a. Their profession seems to exercise no special influence on their moral character. They are generally smart, somewhat crafty, but not to a degree that would greatly transcend the ordinary. Some are very wicked, but others, on the contrary, are benevolent and genial. One, who died in the spring of 1905 at Narardotitten ( $N a$ 'ha'hdotitten), a village some sixty-five miles above Nulato, was one of nature's gentlemen, if there be any. Another, Makayitar (Makayita'h), who died on March 27th, 1894, was a declared atheist and an open enemy of religion and missionaries. His death occurred in circumstances that did no credit to the standing he had taken as an opponent of religion. It was after he had blasphemed late in the night, challenging Alnighty God, "if he only existed," to jut an end to his life, that, in the early morning he went out for the necessities of nature, and, as Arius of old, died in this act.

A shaman is always supposed to die in the same way as he makes other people die, i.e., his soul is eaten up by a spirit. I could obtain no particulars as to how this eating is done, but it is always the first and the last saying which one hears about a dying or dead medicine-man : "A spirit is eating up his soul," they will say: or "his soul was eaten by a spirit." Such is the summary of their funeral orations.

One might be curious to know whether they themselves believe in their supernatural powers, or merely carry on a system of imposition. I believe that some are really convinced that they can do something, at least, to relieve the sick, and such was the case with the Narurdotitten medicine-man whom I have just mentioned. But against this solitary instance I was personally acquainted with four Shamans who acknowledged their utter powerlessness. Two of them are still 
alive, and one even on his way to conversion. I must be excused from giving their names. They both assured me that they make it a point always to return the gifts they receive for their performances, because they say they would feel as though they were stealing if they were to keep them. Their wives concurred in the same assertion. But among Ten'a, two witnesses are not always a sufficient guarantee to the truth of such a statement.

The two others died in 1900. They were held in great repute and had perhaps the most intelligent and bright eyes that I have ever seen. One of these, Say'o, was himself the son of a medicine-man. The other, called Nedzaratiya or Rudzota (Nedza'hatiya, 'Hudzota), had, I think, more clients at Nulato and in the neighbourhood than all the other medicine-men put together. Father Ragaru assisted them during their last illness, and they both owned to him that they had never believed in their magical power, that they had been anxious for a long time to get out of their awkward situation, but were morally constrained to persevere in it by the fear of incurring universal reproof, if they had given it up. People, they alleged, would have considered them as mean and stingy fellows who refused to help the sufferers when they had the means to do so. They both authorised the Father to make this declaration public.

I may add that the medicine-men have absolutely nothing to do with real medicine. The only medical practices which I have witnessed among the Ten'a are puncturing, and the preparation of spruce-tea, and of a decoction of a bush resembling juniper. The puncturing, which consists in thrusting a small pointed blade through the skin previously seized and held up between the thumb and forefinger-just as whites do with the hypodermic syringe-is their method of blood-letting. It is performed by women, generally old women, who have had much practice. The two decoctions alluded to are prepared by anyone who wishes to use them. The medicine-man never interferes with those, not even as much as to advise the patient to recur to these natural remedies.

\section{Appendix I.}

\section{Foreign and Native Words USed in this PaPer.}

To comply with the request formulated on p. 86 of Notes and Queries, I subjoin a list of the foreign words used in the foregoing pages, each of them being written in capitals, and accompanied with some remarks when these seem to be of interest or value.

\section{A. Words used by English Speakers and which may be considered as Anglicized.}

INGALlK, pron. ïn'galik; $p l$. Ingaliks.-A term of contempt by which the Ten'a were designated among their Eskimo neighbours, and which was adopted by the Russians. Probably from the Eskimo : Inkẹlik, pl. Inlee lit, the lousy ones, from inkek, pl. inket, louse-nits. 
InNōKo, pron. ĭnŏk'ŏ.-Also heard as Unoko and Unokஷ். The maps have constantly the spelling: Innoko. The name of an affluent of the Yukon, from the south side. The word is not Ten'a, as the variety in pronunciation shows, and has no meaning in the Ten'a language. The native name for this stream is Eurno, generally pronounced Euron, by a usual transposition, and stands for Zukatno, i.e., fish-river, from $t u k \alpha$, fish, and the suffix tno, meaning river.

KaltaG, pron. kăl'tăg.-A trading post on the Yukon River, about forty miles below Nulato. From this point an overland route, known as "the Portage," goes to the sea-coast, whence a winter trail exists to St. Michael. The post is so called from the Indian name of a locality situated opposite to it, on the south bank of the Yukon, and termed Kattor, viz., amongst the king-salmon, from $K a t$, king-salmon, and the suffix tor, of time or place, meaning among or during.

KosEREFsky, pron. Kŏs'ěrĕf'skŭ.-A Russian name, more or less disfigured, said to mean Leather-Village. The place is located about 240 miles below Nulato on the north bank of the Yukon. It is the last village of the Ten'a, the next one, Paimiut, situated twenty miles further down the river, being a settlement of Eskimo.

KoyUkUK, pron. kŏ'yükük.-The name of a large affluent of the Yukon, on the north side. It empties into the Yukon about twenty miles above Nulato, and a trading post, known as Koyukuk Station, is located on the Yukon, within two miles of, and below, the confluence. This trading post has absorbed the Indian village which used to be about a mile above the actual site. Various etymologies have been proposed for the name, all unsatisfactory.

Nulato, pron. Nōōlă'to.-Trading post dating from 1838, situated on the north bank of the Yukon, in $158^{\circ} \mathrm{W}$. long. and $64^{\circ} \mathrm{N}$. lat. The name is from the Indian word Nulartor, viz., among the dog-salmon; from nulara, dog-salmon, and the suffix tor, among or during.

PARKIE.-Ivan Petrof spells this word parkee, and adds: "a Kamchatkan word; upper garment of fur, with small head opening and sleeves, varying in length" (Compilation of Narratives of Explorations in Alaska, Washington, Government Printing Office; 1900, p. 108). He should not have omitted to mention the hood and its trimming of thick leng-haired fur, which forms a prominent feature of it.

TANANA, pron. Tăn'ănă.-A large affluent of the Yukon on the south side. Within two miles of the confluence, on the north bank of the Yukon, is the trading post and settlement formerly called Tanana Station, now termed Tanana. A commercial company has tried to change this name to Weare, in honour of one of its principal shareholders, and the military post stationed there is called Fort Gibbon by the War Department. Hence the same little spot is called by five names, viz.: Tanana, Tanana Station, Weare, Gibbon and Fort Gibbon, which is as confusing as it is unnecessary. It has, besides, its Ten'a name, viz., Rorododetłattten, meaning: "the place where 
the wood has been chopped," the lumber camp as it were. The word Tanana is probably of Ten'a origin.

Tozikakat, pron. Tozïkä'kăt.-A native camp, some seven miles below Tanana. The word is Ten'a and means the mouth of the Tozitno or Tozi River. This stream is an affluent of the Yukon, on the north side, and the camp is located at its mouth. A river is designated in Ten'a by its name, followed by the suffix tno (sometimes shortened to no), which means river. This suffix is replaced by dlot, to designate the head-waters, and by kakat, to designate the mouth. Thus, the river just mentioned is called Tozitno; its head-waters: Tozidlot; its mouth, Tozikakat. Similarly we have for the Rotol River: Rotoldlot, Rotolno, Rotolkakat, etc. In the lower dialect kakat is pronounced tsakat and tcakcat, i.e., tshakat.

\section{B. Words not Anglicized.}

The following having no orthography sanctioned by use, I write them according to my ordinary alphabet, and I add the transcription in the alphabet given on p. 173 of Notes and Queries. In my alphabet:

1. The apostrophe (') stands for an aspirate, very slight indeed, but perfectly distinct, which occasionally comes near to our $h$ in hand, etc. A fair approach to this sound can be obtained by making a very slight pause between the letters which it separates. It is not represented in Professor Max Müller's alphabet.

2. The stroked 1 (f) stands for the palatal or lateral l, well known to philologists. It may be the sound represented by $l$ in Professor Müller's alphabet, but I cannot make sure of it.

3. The $\mathrm{r}$ stands for a sound which varies according to the localities, from the sound of English $\mathrm{r}$ in car, to the sound of German ch in Buch (or the r grasseye of the Parisians). The soft sound is heard in the upper tribes, from Tanana down to Nulato ; the harsher one prevails below Nulato. This is evidenced in the forms, Anglicized, Nulato and Kaltag, where the same suffix tor has become to, where the r was pronounced soft, and tag where the $\mathrm{r}$ was pronounced hard.

4. The $\mathrm{h}$ stands for German ch in Ich, i.e., 'y, in the alphabet of Professor Max Müller.

\section{Proper Names of Persons.}

'Ten'a names are individual. The name given to a child is commonly the first incorrect or outlandish word which he or she pronounces, or which is said about him or her. To this word is often added the suffix $n \bar{o}$, probably connected with the root no, life, for the females; and it was once customary to add the root to, father, for the males. But this latter practice has fallen intọ disuse. 
DAT'ON.-According to alphabet, p. 173 of Notes and Queries : dat on.

KAYINELE'AN-Kayinelan. May mean: "he looks as though he were beaten, overcome," or : "you have overcome him for your own advantage."

KAPsul, kapsul.-Apparently a nickname given by the Russians. The man's genuine Ten'a name is : Makayusla me-to.

KATs, kats (the $a$ is long or protracted)-probably identical with the root kats, to stare.

KoLtsIK, kolstik.-Probably a Russian word, disfigured.

MakayitaR, Makayitar or Makayita'h.-_"He throws him down upon it," or some similar meaning.

Nedzaratiya, Nedzaratiya or Nedza'hatiya.

Neraila, Neraila or Nebaila.-Said to be a corruption of the Russian form of Michael.

Rudzota, Rudzota or 'Hudzota.

SAYo, Sayo.

SURARloe, Surarlot or Su'ha'hloł.

Tinénka, Tirenka or Ti'hénka.-Probably a disfigured Russian name.

TsaIKA, Tsaika.-Seems to be : tsai ka, "I want tea." Tsai, in lower dialect, tshai, means tea-a Russian import; $k \iota$, denotes desire.

\section{Proper Names of Places, ete.}

KAYAR, Ka'yar or Kä'ya'h.-Literally : village, or the village. A stretch of lake and timber country, opposite Nulato, on the south side of the Yukon, where the lower tribe Ten'a used to have several villages. They still keep up the practice of going there for a month or two every year, during the freezing, and some years also during the breaking of the Yukon. Spelled Kaiyuh on the map of Alaska, printed by the United States Geological Survey (Preliminary Edition, 1904).

Kodilkakat, Kodilkä'kat.-Mouth of the Kodilno or Kodil River, an affluent of the Koyukuk, from the west side. The Kodil is spelled Kateel River on the map of 1904.

KoYÉKAsten, Koyekasten.-A small village some eleven miles above Nulato, on the north bank of the Yukon; also called, Koyekasron. The final ten designates the place where or the time when; the final ron is a preposition meaning at. Thus, Koyekasten means the place of the clay; Koyekasron means at the red clay. There is a deposit of clay in the neighbourhood.

Narardotieten, Narardotiłten.-A large native village about sixty odd miles above Nulato, on the north bank of the Yukon River. The name means the place where we carry the canoe, viz., a portage, and alludes to an overland portage to the lakes, whither the natives used to carry their canoes. When the telegraph stations were established by the Signal Corps of the Unitẹ Ștates Army, Lieutenant George Gịbs endẹvoured to have this name 
adopted for the station there located and spelled it Nahochlatilten. It went under that name from 1901 to 1904, when the appellation being found decidedly too inconvenient, was changed to Louden, the one actually in use. The natives of Narardotitten are remarkable above all other Ten'a for the elegance and accuracy with which they speak their language, as well as for their distinct and harmonious pronunciation.

Nikulikakat.-A small village situated six miles below Nulato, on the north bank of the Yukon. Its people have their summer camp at the mouth of the Nikuliratno, a small affluent of the Yukon, whence the name. But the winter village is two miles above the mouth of the creek.

RoDoKaKaT. - A middle-sized village, formerly very large, about four miles below Kaltag, on the north bank of the Yukon. The name is a generic term meaning the mouth of a river. A small affluent joins the Yukon there and is also called by a general term: Tokotno, the inland creek.

RotolNo, Rotolno or 'Hotolno.-An affluent of the Yukon on the south side. It joins the main river about twenty-five miles below Kaltag, at Rotolkakat. opposite a small native village called Madzatetsef'ihten, and very inappropriately surnamed by the whites Lower Kaltag.

Tartsenibanten, Tartsenibanten.-A once populous settlement, now reduced to two cabins, on the point of an island in the Yukon River twenty miles below Nulato. Opposite the camp, on the north bank of the Yukon, a cabin has been erected for the use of the mail carriers, and is known as Half-way Cabin, from its being mid-way between Nulato and Kaltag.

\section{Other Words.}

A£тA, Atta.-A familiar spirit. Probably from the root-suffix $t t a$, male.

ESEYEN, Eseyen.-Verb intr., I conjure, I witch, expresses the performing of incantations to call or send away devils. Root: yen.

Karunih, Karuni'y or Ka'huni'y.-The amulet or talisman of the medicine-man. It has a spirit connected to it.

Kотмі, Kotni.-Literally : something speaks, the "something," represented by the indefinite pronoun $k e$, being a spirit. Root: $n i$, to say.

Mel-KeTseTlkelen, Mel-Ketsettkelen.-The one whom we hanged, literally, the one around whom we tied something. $M e$ is the object-pronoun of third person, $\mathrm{him} ; l$ is a preposition meaning around; mel, him-around. Ke is the indefinite pronoun, something; tsettket, we tied, first person, plural of Past indicative of the verb ettket, I tie. This Past regularly implies that the object remains tied at the time of the utterance; if not the same person of the verb would be, tserettket. The final en is a suffix having the force of a relative pronoun, and corresponding to the one who or whom.

Nekedzaltara, Nekedzaltara or Nekedzalta'ha.-Spirit or spirits. Probably means the quick moving or the quickly moved thing. 
Niæ. ro Tenatadlerunten, Nit ro tena tadlerunten or Nił ro tena tadle'hunten.The place where we are tied to each other. Nit, reciprocal pronoun; ro, preposition, to ; ten' $a$, object-pronoun of first person plural, us; tadlerun, third person singular (passive) of the form of actual duration from the past indicative of dettrun, I tie; ten, the place where.

SEir, Sen.-A spirit, especially as connected to a Karunih.

Shaman, sä'man.-A Kamchatkan word for sorcerer or medicine-man (Ivan Petrof, Compilation, etc., p. 108); never used by the Ten'a amongst themselves, but only when speaking to foreigners.

TELEBEGA, tel'ebega.-A small white fish, 8 to 10 inches in length somewhat oily but quite palatable, common in the Yukon.

Ten'A, Ten'a.-Man. Differs from the object-pronoun tená, us, by the accent and the aspirate'.

Teyen, Teyenen, Teyén, téyenen.-Scrcerer; medicine-man. If necessary, when speaking of a medicine-woman, the word soltan, woman, is prefixed: soltan teyenen, a medicine-woman. See above: eseyen.

Tsonteye, Tsonteye.-Spirit. Literally, the bad thing: tso, bad, neta, third person singular, present indicative of esta, to be, the verb of circumstance ; and suffix $y e$, the thing which. Spirits, in the language, are not persons but things, as the animals.

Uskun, Uskun.-I prompt by paying, I bribe, as it were. Evidently from the root kun, fire, which in this peculiar form would have the force of I intend to burn, I mean to set fire to.

\section{APPENDIX II.}

\section{Words Belonging to THE MEdicine-MaN's CRAft.}

The following words are here appended as illustrating to some extent the belief of the Ten'a concerning their medicine-men and the practices indulged in by these. The list is by no means a complete one. Although it would be necessary to possess a fair knowledge of the language in order to understand thoroughly the force of these and similar expressions, they may afford, even to the uninitiated, an insight into the way the Ten'a think and speak about the craft.

In writing these I use only my ordinary alphabet, believing that its value may be easily estimated from the comparisons made throughout Appendix I. The words are arranged in the alphabetical order of the roots, although the reader might be induced to think differently from the appearances. It would require too much of a grammatical dissertation to explain here why. I consider the root taih, for instance, to be the fourth form (iv) of the root $l a$.

$b a$, to swim.

dzc no-kedebaihten, a cavern from which a spirit is accustomed to come forth and jump in the water. 
$d a t$, motion not under control of the will, has 12 different forms, of which I quote only:

i. ido no-karanegedat, I enter a house. Expresses that the subject who enters is a multitude, viz., a medicine-man with spirits.

iv. (tar) nekedzaltara, spirit.

dzatar, the dead-dance, or the dance by which the dead are supposed to be brought back to life.

dzatar kelek, the song of the dead-dance.

no-to-karaledar, a spirit jumps into the water.

no-to-kettar, I cause a spirit to jump into the water.

ma ka dza esetar, I dance for him to be brought back to life.

v. (lih) kade ni danettlih, I strike (him) with poverty, I reduce (him) to want. me-ni rat-danettlih, I strike him with lameness, I cripple him (by magic or witchcraft).

'ih, to see.

ro do-rodanetl'ih, I foretell (foresee in word) the death of-death is not expressed but understood.

'ih, stealth.

'aba ko ro-denarast'il, I guard against disease, I dodge sickness-aba, means disease, sickness, sore, etc.

'ih; to eat.

me nokobedza es'on, I eat his soul-nokobedza, soul.

tena nokobedza yi-rei'ih, they eat our souls.

kaih, cramp.

a-ketlkaih, I cause a cramp to, I cramp.

koih, to run.

se yi no-kelekoih, a spirit invades me.

kun, fire.

uskun, I prompt or bribe a medicine-man; I propitiate.

udasokun, I burn an offering to.

kudasokun, I make burnt-offerings.

la, to put or place. Has twelve forms, as root dat. The following only need be mentioned :

i. dza tseleyar, we dance to bring the dead to life.

tte tesla, I put in the fire, viz., I make a burnt-offering of (object plural).

tte teslaih, the same, in frequentative form.

me yeka kanaga delaih, in it words are put, a wireless telephone, by the devils; said to have been used by medicine-men to communicate with each other when at a distance.

iv. (taih).

nen ko no-letttaih, I bring back to life (a dead person).

se yi no-zek-keletaih, a spirit invades my body.

ta-met-sittaih, I am entranced, my soul being carried downwards.

ya-met-sittaih, the same, with upward motion. 
v. ('oil).

dza runes'oih, I become a medicine-man-literally: I show out a thing (abstract), I set forth an abstract object.

no-nett oih, I bring back to life (a dead person). Perhaps from root'oih, tò go.

lit, mental actions or changes-the frequentative form is lek.

me tse yini-teslek, I turn my mind to it; the object being a spirit, the result will

be to have him come.

ro ni yini-neslit, I help by magic or witchcraft.

a-ko runettlit, I reduce to beggary.

teyenyu lonna sor ni yini-ralek, many medicine-men are helping me. Ita, male.

sa attaa ara mor ni yini neslet, I helped him (cured him) by means of my spirit.

ma attaa ketelattran, another spirit has killed his.

raba attaa rono toruno ta-rattloga, ei teyenyu; whilst their spirit is alive the medicine-men do not die.

ma attaa keten nekedzaltara yo'on, another spirit is eating his. $\hbar$ ice. ice.

nen yar luu, the underground ice, which is supposed to be everywhere under the earth surface. The medicine-men in their trances often visit this nucleus of ice unknown to our scientists.

nar, become.

naradenitna, ghosts.

$n i$, to say.

tse desni, I say to him, meaning: I make him a present to him to help me by magic, practically the same meaning as uskun.

nih, action.

resnih, I move as a spirit or ghost; expresses the motion of spiritual beings.

karaninit, the thing (i.e., spirit) has come.

sa-karaninik, a spirit has come into me.

me tse ratettnith, I send (a spirit) to him.

nekedzaltara mo ro kerélaye raninik, a spirit having no equal has come.

'a, position or location.

ketaka rotal'o tse rora aba yi-zilaih, we (i.e., they) are sick in a way which is beyond (our) power.

rat, to flee.

yar degarat, I invade his place by my spirit; this is done by sending the spirit under ground to stop beneath the place where the other man is resting or sleeping, by which, first the spirit of the sleeping man, and then the man himself, is made to die.

ulegdrat, I send my spirit to pass underneath him, not stopping as in the preceding case; the result is the same. 
nekedzaltara me yeka utdlerat, tseyero to-ttlon, a spirit passed under him, and thus he died.

nit yar zileraiht (frequentative), we invade each other's place. ttan, to abstain.

kota, nelekure intttan, henceforth abstain from hot food.

tor, to disappear, to vanish.

no-rottor, ketetttor, I cause things to disappear suddenly.

ro-detegetor, I cause myself to disappear.

'uihtt, to swim, in a crowd.

dza no-kele'uihttten, a place from which spirits swim out. yen, to conjure.

mor eseyen, I perform incantations against him or in his favour. tso-ttakaye a-egeyen, I invoke wicked spirits.

\section{APPENDIX III.}

The following is a sample of Ten'a folk-lore, which has been thought to have enough bearing on the subject treated, to serve as a further illustration of Ten'a thought about the matter; written with my ordinary alphabet. An interlinear word for word translation is given with the text; a current rendering follows.

\section{Nen ma-atłniken.}

The Cripple.

Kayar rulan. Tseyerotse teyenen ${ }^{1}$ me-ten'a yu'an ledo, ${ }^{2}$ keiłkanen. $^{3}$ A village there is. And a medicine-man's child apart stays, one abstaining. Ratte $\quad$ salno $^{4}$; tsaratte t7etał royan sodet, sonat.

and we have started on the hunt; and at night only we shall go, we shall go hunting. Nenkoroten'a lon. Ataratte yi-met-tseinoletik to-roron ni ranino. People many. Presently we shall sleep in order that they have stopped. i.e., to the end that we may sleep, for a sleep.

Aruroyeł ronten: "Mor ni norno-ye rulan-te to 'é meł ara Then suddenly: "That after which you hunt where it is is this sleep by lordzet-ten? taka! tłetat sonat;" zelerus toruno where you lie down? up! at night we shall hunt"; we shout whilst i.e., whilst she shouts.

1 It is understood immediately by a Ten'a hearer that this medicine-man is the cripple mentioned in the title. The connection is not so plain to us.

${ }^{2}$ Stays apart, viz., during the month, or the year, which follows the first appearance of the catamenia. Hence it becomes evident that she is a woman. Nothing else marks it in the text.

3 Abstaining. During the separation just mentioned the women practise abstinence, very strict during the first month, less so for the remainder of the first year.

4 The first person plural is used for an indefinite subject, as will appear often in the following lines. 


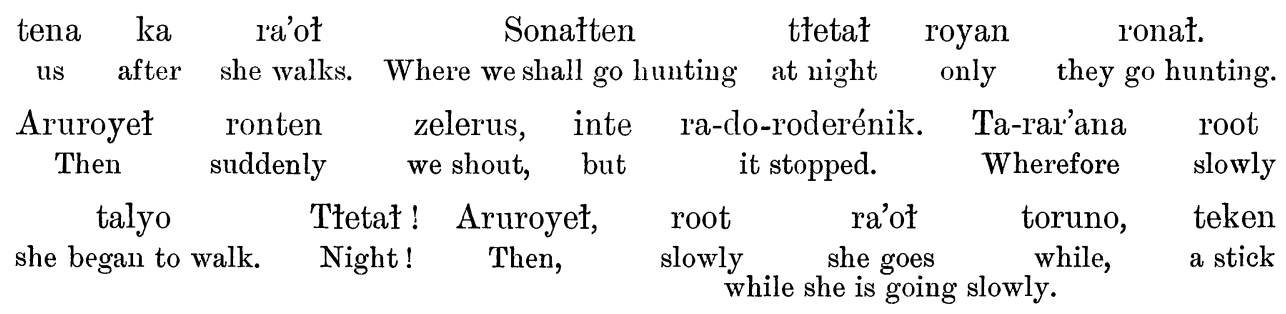

\begin{tabular}{|c|c|c|c|c|c|c|c|}
\hline $\begin{array}{l}\text { ade } \\
\text { herself } \\
\text { ahead of } h\end{array}$ & $\begin{array}{l}\text { otse } \\
\text { efore } \\
\text { self }\end{array}$ & $\begin{array}{r}\text { dod } \\
\text { she puts } t\end{array}$ & $\begin{array}{l}\text { liht1 }{ }^{1} \text {. } \\
\text { the ground. }\end{array}$ & $\begin{array}{l}\text { No } \\
\text { Unde } \\
\text { from }\end{array}$ & $\begin{array}{l}\text { ka rotse } \\
\text { eath from } \\
\text { derground. }\end{array}$ & $\begin{array}{l}\text { zelerus, } \\
\text { we shout, }\end{array}$ & $\begin{array}{l}\text { ittak ; } \\
\text { it is heard ; }\end{array}$ \\
\hline $\begin{array}{l}\text { aruroyet } \\
\text { then }\end{array}$ & $\begin{array}{l}\text { ko } \\
\text { this }\end{array}$ & $\begin{array}{l}\text { teken } \\
\text { stick }\end{array}$ & $\begin{array}{l}\text { ade ni roc } \\
\text { disapp }\end{array}$ & $\begin{array}{l}\text { nen. } \\
\text { d. }\end{array}$ & $\begin{array}{c}\text { Tseyerotse, } \\
\text { And so, }\end{array}$ & $\begin{array}{l}\text { kar } \\
\text { back h } \\
\text { she stal }\end{array}$ & $\begin{array}{l}\text { ade yef } \\
\text { erself with } \\
\text { ted back on }\end{array}$ \\
\hline
\end{tabular}

$\begin{array}{cccccc}\begin{array}{c}\text { no-tafletset; } \\ \text { she jerked } \\ \text { a sudden }\end{array} & \text { tseyerotse } & \text { kar } & \begin{array}{c}\text { no-tafleyo. } \\ \text { and so }\end{array} & \text { back } & \text { Na-radol; began to go. She goes back ; } \begin{array}{c}\text { te-to } \\ \text { her father to } \\ \text { to her father }\end{array}\end{array}$

$\begin{array}{cccccc}\text { no-tałleyo. } & \text { Aruroyel ronten } & \text { kun-kat rotse } & \text { na-radol; } & \text { yuni } \\ \text { she began to go. } & \text { Then } & \text { suddenly } & \begin{array}{c}\text { a fire-place towards } \\ \text { towards a fire-place. }\end{array}\end{array}$

\begin{tabular}{|c|c|c|c|c|c|}
\hline \multirow{2}{*}{$\begin{array}{c}\text { ronte } \\
\text { unexpectedly } \\
\text { no dini ! } \\
\text { you foretell! }\end{array}$} & $\begin{array}{l}\text { rodalkun. } \\
\text { there is a fire burning. }\end{array}$ & $\begin{array}{l}\text { Aruroyet } \\
\text { Then }\end{array}$ & $\begin{array}{l}\text { tseyitf'osk } \\
\text { we sneezed, }\end{array}$ & $\begin{array}{l}\text { ittak. } \\
\text { it is heard. }\end{array}$ & $\begin{array}{l}\text { "Ket1 } \\
\text { "Food }\end{array}$ \\
\hline & $\begin{array}{l}\text { ałoo } \\
\text { in vain }\end{array}$ & $\begin{array}{l}\text { duruniayu! } \\
\text { not say! }\end{array}$ & \multicolumn{2}{|c|}{$\begin{array}{l}\text { nen ma-attniken } \\
\text { the cripple }\end{array}$} & $\begin{array}{l}\text { me-ter } \\
\text { 's ch }\end{array}$ \\
\hline $\begin{array}{l}\text { se no } \\
\text { me-around } \\
\text { around me }\end{array}$ & $\begin{array}{c}\text { denirudettis }{ }^{3} \\
\text { ay she get black-faced }\end{array}$ & $\begin{array}{l}\text { tse } \\
\text { this }\end{array}$ & $\begin{array}{l}\text { rono-te } \\
\text { you fo }\end{array}$ & $\begin{array}{l}\text { rola;" } \\
\text { perhaps ;" }\end{array}$ & th \\
\hline
\end{tabular}

ko kun a-didonen te-denitsen. Tse neleket-tsen: "Atłeye to nekedzaltara the one sitting at the fire what he says. And (she) being afraid: "This is a devil

\section{ko le-deniye," ni. Tseyerotsaratte oih yatsetse}

the thing that speaks," she says. And upon this (her) snow-shoes in the opposite direction ni no niłtatł, tse ten roralka réyo, tseyerotse yuur no-tałleyo. she directed, and the trail-alongside-of she went, and thus over there she began to go. out of the trail but along it.

Ko nekedzaltara an ulyo, tse ro no-tadlekok, te-to ro no-ilekok. This devil off she passed, and up she began to run; her father-to she ran back. to her father

1 This could be understood in two ways; 1st, as I have translated, to say that she feels the ground ahead with a stick; or, 2nd, that a stick appears walking alone by itself, ahead of her.

${ }^{2}$ One who sneezes always addresses thus the cause of his sneezing, supposed to be a devil ; in this he formulates a wish. Here the speaker expresses first the usual wish for food, then he emphasises it by wishing that it may not be frustrated, then he expresses another wish for the unfortunate girl.-See next note.

${ }^{3}$ May she become black-faced. This implies the wish that she may starve, as the Ten'a think that long fastings render their skin darker than it naturally is. Their long fasts generally occur in the spring-hunt, when the game happens to be scarce, and it is a fact that they come back with a sun-burnt complexion. But this is traceable to the very strong sunshine and the want of soap more than to their starving. I could never notice that those who had had plenty to eat were less sun-burnt than the others. 


$\begin{array}{ccccc}\text { Tseyerotse ronten } & \text { me-to } & \text { yin-do-rodaltlet }{ }^{1} ; & \text { tseyerotse } & \text { nekedzaltara } \\ \text { And suddenly } & \text { her father } & \text { was angry at the words ; } & \text { and } & \text { the devil }\end{array}$

$\begin{array}{ccccc}\text { to-ltlon, ko } & \text { teyenen } & \text { yelatfnan }^{2} & k \hat{a} & \text { te-yilor. } \\ \text { died, } & \text { this medicine-man } & \text { killed it } & \text { as } & \text { it were. }\end{array}$
Tseyerotse te-to ro taldo. Ketła kā ta-ratalta, And so her father-with she begin to stay. Food-in want of they began to be, tseyerotse mén-kat rotse te-to tattror. in want of food and so a lake towards her father she carried on a sled. Fish in-search-of towards a lake in search of fish

tseterézon iru. Tseyerotse me-to ratte yero naltan we dug holes in the ice, in vain. And so her father thus lay down ko baaba kāt. ${ }^{3}$ Tseyerotse noy'a-leł ra-do-no-detadle kuł, tse (in) this food wantof. And so a beaver-skin she brought into the house, and from want of food

tłe yederéłkut. ${ }^{4}$ Met-inadleten; dza nilet; tłi niyo. Aruroyeł ronten in the fire she put it. She went to sleep; she awoke; out she went. Then unexpectedly yutti men-kat tu kala ${ }^{5}$ ko tu nitkatse toko ledak. down the bank (in) the lake ice none; this ice on both sides on the beach is gone. Noko diyo; tu ledak. Euka kéłoke ulnik te-to tse to Down the bank she went; the ice is gone. Fish one she took; herfather to up no-tałleyo tseyerotse tłé yederéftlak, ko łuka. Ko ye not she started back; and thus in the fire she putit, this fish. This its flesh ulnik, te-to lo yeréłdatł; tseyerotse me-to nenoko no-tatłnik. she took, (in) her father's mouth she thrust it; and then her father stood up. Rott noko diton; tuka rotł katse to-no-tadlerok. A sled down the bank she brought; fish the-sled-on up she began to bring repeatedly. Me-to no-utlezut ${ }^{6}$; ko soltan ratte tatleyen: Her father recovered; this woman on the other hand began to practise the medicine : te-to kadeyor.

her father she became as.

\section{Transtation.}

In a village, the daughter of a medicine-man was set apart for the days of her abstinence. The whole population started for the hunt; they were to go

1 Viz., at the relation of what had happened to her.

2 Killed it, but did not destroy it, as appears further. He was dead, "as it were."

${ }^{3}$ This want of food is the work of the devil which has been, as it were, killed by the medicine-man. A Ten'a understands this at once, but we need a bit of explanation.

${ }^{4}$ Burning this skin, which is valuable, was an offering to the angry devil, by which he was appeased.

${ }_{5}$ This and the following happy events show the advantages of having propitiated the evil one.

${ }^{6}$ Recovered. This may mean from his temporary weakness, or even from his cripple condition. 
only during the nights on this hunting expedition. They were many. They had just camped for a sleep, when someone exclaimed, "What! is this the place where you will the game you are looking for? What means this going to sleep now? Get up! it is at night that we must go" ; and, so saying, she was coming on their track. They had to go to the hunting ground by night.

Suddenly a shout was heard; then all became silent again. She began to walk cautiously in the dark, feeling the ground ahead with a stick. Another shout was heard coming from under the ground. She started back, whilst the stick vanished from her eyes, and she turned back. She was going back to the place where she had left her father, when she beheld a camp-fire ahead of her, on the way, and heard a sneezing. "A presage of food! May it be a true one! A presage, perhaps, that the cripple's daughter will starve whilst going around my abode," spoke the one who sat by the fire. Fear seized her: "It is a spirit that speaks," she said, and she turned her snow-shoes off in the opposite direction, and left the trail. Having passed the spirit at a distance, she started to run, and ran back to her father. When she told him what had happened, he was quite angry ; so much that the spirit died, as it were, from the treatment it received from him.

She remained with her father. As they had nothing more to eat she carried him on a sled to a lake. They dug holes in the ice to catch fish, but they failed in their attempts, and her father was reduced to lie down from weakness. Then she brought a beaver-skin into the house and burnt it. She went to sleep, and, when she woke up, she went out. There was no more ice on the lake; it had all gone to the shores. She went down the bank; the ice was gone. She caught a fish, and went back to her father. In haste she put it on the fire, took some of its flesh an'd put it into her father's mouth. Immediately he raised himself from the ground. She brought a sled down the bank and began to go up and down bringing fish. Her father recovered, and she, in her turn, became a medicinewoman; she became what her father had been. 